\title{
PARADIGMA PENDIDIKAN PROFETIK DALAM PENDEKATAN PEMBELAJARAN TEMATIK DI MADRASAH IBTIDA'IYAH
}

\author{
Muhamad Khoirul Umam \\ STAI Badrus Sholeh Purwoasri Kediri \\ khoirul_umam2426@yahoo.co.id
}

\begin{abstract}
Good learning should have the goal of teaching learners to obtain learning outcomes with a combination of cognitive, affective, and psychomotor aspects in balance with the values of religious character. thematic learning as a new approach to development in elementary school and balanced with paradigm of prophetic education as the reinforcement of morals learners early on. Because the prophetic education identified as an educational paradigm seeks to collaborate between educational systems that focus on moral and cultural values with a modern education system (new education) that develops humanitarian values. Problems with the process, model, and implementation of thematic learning at elementary school. But it needs to be seen anyway. The role of educators in elementary school that Islamic should be can't be replaced by other devices, such as television, radio, computers, and so forth. This matter happened participants educate elementary school still need guidance and assistance of adult to develop all ability or potency that is influenced as well as formation of morality commendable. So raises the question of research how learners are prepared as a person as well as a form of rahmatan lil'alamin value that is intended as a standard of educational success measured on learning and learning with the community by presenting thematic lessons to learners first from the perspective of prophetic education taken from the values of the role model of the Prophet ?. To answer this research question, researchers collect data by method. Then after the data collected, analyzed. This is an alternative choice modeling the values prophetic into a Perspective of the Educative Character of Learners
\end{abstract}

Keywords: Profetic Values, Thematic Learning, the character of learning

\section{PENDAHULUAN}

Pendidikan profetik yang merupakan proses transfer of knowledge dan transfer of values yang bertujuan untuk mendekatkan diri kepada Tuhan Yang Maha Esa dan alam ciptaan-Nya serta dalam memahami untuk membangun rumpun masyarakat social yang idealnya bermanfaat bagi sesama manusia atau memiliki manfaat terhadap kelompok masyarakat. Dalam pendidikan profetik seyogyanya peserta didik dipersiapkan sebagai pribadi sekaligus bentuk dari nilai-nilai rahmatan lil'alamin yang diperuntukan sebagai standar keberhasilan pendidikan yang diukur atas capaian pembelajaran yang menginternalisasikan dalam pribadi dan teraktualisasi secara social masyarakat.

Pendidikan profetik yang diidentikan sebagai paradigma pendidikan yang berusaha melakukan kolaborasi antara sistem pendidikan yang fokus terhadap nilainilai moral serta religious culture dengan sistem pendidikan yang modern (new educations) yang mengembangkan bentuk nilai-nilai kemanusiaan (humanism). Dalam perjalananya pendidikan profetik telah dikembangkan dalam bentuk tiga lokus dimensi yang mengarahkan perubahan terhadap kelompok masyarakat yang berupa: humanisassi, liberasi, dan transendensi. Paradigma pendidikan profetik dapat dipahami sebagai seperangkat teori yang tidak hanya menjabarkan dan mentransformasikan gejalaa-gejala social, dan mengubah sesuatu yang hanya demi perubahan (change) 
The $3^{\text {rd }}$ Annual International Conference on Islamic Education

24-25 Februari 2018

Paradigma Pendidikan Profetik

Muhamad Khoirul Umam - STAI Badrus Sholeh Purwoasri Kediri

namun lebih dari pada itu yang mengarahkan akan perubahan atas dasar cita-cita etik dan keprofetikan.

Menengok sedikit pendekatan pembelajaran tematik yang merupakan kumpulan mata pelajaran yang dikemas secara terpadu dari bahan kajian sejarah, geografi, ekonomi, politik, antropologi, psikologi, dan ekologi dan juga tentang makhluk hidup. Salah satu tujuan konsep utama pembelajaran ini guna membina pengetahuan peserta didik tentang pengalaman individu dan lingkungannya dalam kehidupan social bermasyarakat. Upaya untuk mencapai tujuan di atas dapat ditempuh melalui pengembangan kemampuan peserta didik dalam praktek pembelajaran yang menyeluruh dan terpadu. Pembelajaran yang baik harus mempunyai tujuan membelajarkan peserta didik untuk memperoleh hasil belajar berupa perpaduan antara aspek kognitif, afektif, dan psikomotor secara seimbang dengan nilai-nilai karakter religius. Hal ini berarti, sistem pembelajaran harus menempatkan peserta didik sebagai subjek belajar, bukannya sebagai objek belajar. Adapun faktor-faktor yang berpengaruh terhadap sistem pembelajaran diantaranya faktor pendidik, peserta didik, sarana, alat dan media, serta faktor lingkungan.

Pendidik dalam proses pembelajaran memegang peranan yang sangat penting. Peranan pendidik di madrasah Ibtidai'yah yang notabennya berasaskan Islami tak mungkin digantikan oleh perangkat lain, seperti televisi, radio, komputer, dan lain sebagainya. Hal ini dikarenakan peserrta didik madrasah Ibtidai'yah masih memerlukan bimbingan dan bantuan orang dewasa untuk mengembangkan segala kemampuan atau potensi yang dimilikinya sekaligus pembentukan akhlak terpuji. Oleh karena itu, selain mengajar pendidik juga harus bertindak juga sebagai model, teman pendamping, pemberi motivasi (motivator), dan penyedia bahan pembelajaran (fasilitator) dan sekaligus penanaman akhlak religius. Selain itu, pendidik harus mampu merancang pembelajaran yang tepat untuk meningkatkan hasil belajar peserta didik.

Pembelajaran tematik dapat dilaksanakan dengan menggunakan berbagai model pembelajaran. Model adalah sesuatu yang direncanakan, direkayasa, dikembangkan, diujicobakan, lalu dikembalikan pada badan yang mendesainnya, kemudian diujicoba ulang, baru menjadi sesuatu yang final.

Penerapan pendekatan pembelajaran tematik di madrasah Ibtidai'yah biasa disebut sebagai suatu upaya untuk memperbaiki kualitas pendidikan, terutama dalam rangka mengimbangi gejala penjejalan isi kurikulum yang sering terjadi dalam proses pembelajaran yang dilaksanakan di madrasah-madrasah. Penjejalan isi kurikulum tersebut dikhawatirkan akan mengganggu perkembangan peserta didik, karena terlalu banyak menuntut peserta didik untuk mengerjakan aktivitas atau tugas-tugas yang melebihi kapasitas dan kebutuhan mereka. Dengan demikian peserta didik kehilangan sesuatu yang seharusnya bisa mereka kerjakan. Jika dalam proses pembelajaran peserta didik hanya merespon segalanya dari pendidik, maka mereka akan kehilangan pengalaman pembelajaran yang alamiah dan langsung (direct experiences). Pengalamanpengalaman sensorik yang membentuk dasar kemampuan pembelajaran abstrak peserta didik tidak tersentuh, hal tersebut merupakan karakteristik utama 
The $3^{\text {rd }}$ Annual International Conference on Islamic Education

perkembangan peserta didik usia madrasah Ibtidai'yah. sehingga pembelajaran tematik sebagai pendekatan baru dianggap penting untuk dikembangkan di madrasah Ibtidai'yah dan diimbangi dengan paradigma pendidikan profetik sebagai penguat akhlak peserta didik sejak dini.

\section{HASIL DAN PEMBAHASAN}

\section{Tinjauan Cara Pandang Pendidikan Berbasis Profetik}

Masalah pendidikan sudah lama menjadi pokok diskusi masyarakat Indonesia, khususnya para pengamat dan pakarnya. Diskusi-diskusi tersebut telah menghasilkan berbagai definisi tentang hakekat, peranan serta pentingnya pendidikan. Sejauh perkembangannya selama ini, baik secara konseptual maupun teknisnya di lapangan, pendidikan telah mengalami beberapa fase perubahan. Hal itu disebabkan karena pendidikan selalu mencoba melahirkan konsep-konsep baru dalam mengatasi berbagai persoalan yang muncul di dalamnya. Namun tidak bisa dipungkiri bahwa pendidikan di Indonesia justru terjebak ke dalam sebuah paradigma dan ideologi yang sebagian besar diadopsi dari Barat. Implikasinya adalah pendidikan akan semakin kehilangan ruhnya, atau semakin diper(barat)kan. Liberalisasi di bidang pendidikan, yang berakibat kepada pendidikan yang dikomersilkan, semakin menjadikan masyarakat sulit untuk mengakses pendidikan. Dengan demikian maka peradaban menjadi terancam, karena manusia sudah tidak lagi diposisikan sebagai makhluk paling utama, manusia disamakan dengan mesin dan hewan.

Oleh karena itu, dibutuhkan sebuah sintesis yang paling memungkinkan dalam menyelesaikan beberapa persoalan tersebut. Dibutuhkan konsep pendidikan yang bukan hanya bersifat akomodatif, namun juga harus berangkat dari sebuah paradigma pendidikan yang berkomitmen terhadap kebenaran. Untuk itulah upaya pencarian alternatif dalam bentuk konsep yang selanjutnya akan dikembangkan secara baik dan benar menjadi sebuah keniscayaan untuk dilakukan. Konsep pendidikan yang didesain berdasarkan kebutuhan mendasar manusia. Namun dengan tetap tidak terlepas dari nilai-nilai dasar sebagai pondasi utamanya, Islam.

Sebagai agen perubahan sosial, pendidikan Islam yang berada dalam atmosfir modernisasi dan globalisasi, dewasa ini dituntut untuk mampu memainkan perannya secara dinamis dan proaktif. Kehadirannya diharapkan mampu membawa perubahan dan kontribusi yang berarti bagi perbaikan ummat Islam, baik pada dataran intelektual teoritis maupun praktis.

Pendidikan Islam bukan sekedar proses penanaman nilai-nilai moral untuk membentengi diri dari ekses negatif globalisasi. Tetapi yang paling urgen adalah bagaimana nilai-nilai moral yang telah ditanamkan pendidikan Islam tersebut mampu berperan sebagai kekuatan pembebas (liberating force) dari himpitan kemiskinan, kebodohan, keterbelakangan sosial budaya dan ekonomi. ${ }^{1}$ Kandungan materi pelajaran dalam pendidikan Islam yang masih berkutat pada tujuan yang lebih bersifat ortodoksi

${ }^{1}$ Ahmad Syafii Ma'arif, Islam dalam Bingkai Kemanusiaan dan Keindonesiaan (Bandung: Mizan, 2009), 231. 
The $3^{\text {rd }}$ Annual International Conference on Islamic Education

24-25 Februari 2018

Paradigma Pendidikan Profetik

Muhamad Khoirul Umam - STAI Badrus Sholeh Purwoasri Kediri

diakibatkan adanya kesalahan dalam memahami konsep-konsep pendidikan yang masih bersifat dikotomis; yakni pemilahan antara pendidikan agama dan pendidikan umum (sekuler), bahkan mendudukkan keduanya secara diametral.

Dari pendidikan Islam yang masih cenderung bersifat dikotomis yang selama ini terpisah secara diametral, yakni pendidikan yang hanya menekankan dimensi transendensi tanpa memberi ruang gerak pada aspek humanisasi dan liberasi dan pendidikan Islam yang hanya menekankan dimensi humanisasi dan liberasi dengan mengabaikan aspek transendensi.

Dari beberapa persoalan tersebut kemudian urgensi dari pemikiran seorang pemikir Indonesia (kuntowijoyo) layak untuk kita perbincangkan menjadi sebuah alternatif baru dalam menghadapi persoalan pendidikan bangsa Indonesia dengan konsep pendidikan profetik ala kuntowijoyo. ${ }^{2}$

Kata "profetik" berasal dari bahasa inggris prophetical yang mempunyai makna Kenabian atau sifat yang ada dalam diri seorang nabi. ${ }^{3}$ Yaitu sifat nabi yang mempunyai ciri sebagai manusia yang ideal secara spiritual-individual, tetapi juga menjadi pelopor perubahan, membimbing masyarakat ke arah perbaikan dan melakukan perjuangan tanpa henti melawan penindasan. Dalam sejarah, Nabi Ibrahim melawan Raja Namrud, Nabi Musa melawan Fir'aun, Nabi Muhammad yang membimbing kaum miskin dan budak belia melawan setiap penindasan dan ketidakadilan, mempunyai tujuan untuk menuju kearah pembebasan. ${ }^{4}$ Menurut Ali Syari'ati dalam Hilmy para nabi tidak hanya mengajarkan dzikir dan do'a tetapi mereka juga datang dengan suatu ideologi pembebasan. ${ }^{5}$

Secara definitif, pendidikan profetik dapat dipahami sebagai seperangkat teori yang tidak hanya mendeskripsikan dan mentransformasikan gejala sosial, dan tidak pula hanya mengubah suatu hal demi perubahan, namun lebih dari itu, diharapkan dapat mengarahkan perubahan atas dasar cita-cita etik dan profetik. Kuntowijoyo sendiri memang mengakuinya, terutama dalam sejarahnya Islamisasi Ilmu itu seperti hendak memasukan sesuatu dari luar atau menolak sama sekali ilmu yang ada. ${ }^{6}$ Beliau mengatakan: "saya kira keduanya tidak realistik dan akan membuat jiwa kita terbelah antara idealitas dan realitas, terutama bagi mereka yang belajar ilmu sosial barat. Bagaimana nasib ilmu yang belum di Islamkan? Bagaimana nasib Islam tanpa Ilmu?.7 Dengan ungkapan seperti ini, Kuntowijoyo tidak bermaksud menolak Islamisasi ilmu, tapi selain membedakan antara ilmu sosial profetik dengan Islamisasi Ilmu itu

\footnotetext{
2 M. Fahmi, Islam Transendental: Menelusuri Jejak-jejak Pemikiran Islam Kuntowijoyo, (Yogyakarta: Pilar Religia, 2005), 30.

3 Kuntowijoyo, Muslim Tanpa Masjid, (Bandung: Mizan, 2001), 357.

${ }^{4}$ Muhammad Basyam Rusydi Az-Zain, Sekolah Para Nabi 1 \& 2. (Yogyakarta: Pustaka Marwa, 2007),

5 Ali Shari'ati, Humanisme: Antara Islam dan Mazhab Barat, terj. Husein Anis al- Habshi, (Bandung: Pustaka Indah, 1996), 119.

6 Moh. Shofan, Pendidikan Berparadigma Profetik (Upaya Konstruktif Membongkar Dikotomi Sistem Pendidikan Islam), (Yogyakarta: IRCiSoD, 2004, 131.

${ }^{7}$ Kuntowijoyo, Paradigma Islam: Interpretasi Untuk Aksi, (Bandung: Mizan, 1991), 549.
} 
sendiri, juga bermaksud menghindarkan pandangan yang bersifat dikotomis dalam melihat ilmu-ilmu Islam dan bukan Islam.

Pendidikan Islam yang sekaligus sebagai bagian dari sistem pendidikan Nasional. Secara ideal, pendidikan Islam bertujuan melahirkan pribadi manusia seutuhnya. Dari itu, pendidikan Islam diarahkan untuk mengembangkan segenap potensi manusia seperti; fisik, akal, ruh dan hati. ${ }^{8}$ Segenap potensi itu dioptimalkan untuk membangun kehidupan manusia yang meliputi aspek spiritual, intelektual, rasa sosial, imajinasi dan sebagainya. Rumusan ini merupakan acuan umum bagi pendidikan Islam, yang akhir tujuannya adalah pencapaian kebahagiaan di dunia dan di akhirat.

Dalam pengertian yang lebih luas, pendidikan Islam ingin membentuk manusia yang menyadari dan melaksanakan tugas-tugas ke-khalifahan-nya dan terus memperkaya diri dengan khazanah ilmu pengetahuan tanpa batas serta menyadari pula betapa urgen ketaatan kepada Allah SWT sebagai Sang Maha Mengetahui dan Maha Segalanya. Dalam Surat Al-Baqarah disebutkan pada ayat: 269 yang artinya: "Tidaklah berdzikir kecuali ulul albab". Disini, ada proposional antara dzikir dan fikr dalam sebuah cita-cita pendidikan Islam. Artinya, hakikat cita-cita pendidikan Islam adalah melahirkan manusia-manusia beriman dan berilmu pengetahuan, yang satu sama lainnya saling menunjang.

Dalam mewujudkan cita-cita pendidikan Islam, muncul berbagai problematika dalam pendidikan Islam. Diantaranya krisis dalam pendidikan Islam karena munculnya dikotomi epistemologi antara Ilmu agama (akhirat) dan ilmu umum (dunia), antara Ilmu modern Barat dan Ilmu tradisional Islam. ${ }^{9}$ Selain itu, disebabkan pula oleh sistem pendidikan Islam yang hanya dilaksanakan untuk memenuhi tuntutan yang bersifat formal dan mengabaikan idealisme yang mencerminkan proses-proses pemenuhan tugas-tugas kemanusiaan. Indikasi tersebut cukup jelas, dengan terlihat munculnya dua tipologi pendidikan Islam yakni, pendidikan Islam tradisional dan pendidikan Islam modern.

Pada dasarnya tujuan umum pendidikan Islam, menurut Athiyah Al-Abrasyi dalam Hasan Langgulung menyimpulkan lima tujuan umum yang asasi. Diantaranya yaitu; Pertama. Untuk membantu pembentukan akhlak yang mulia. Bahwa pendidikan akhlak adalah jiwa pendidikan Islam, dan untuk mencapai akhlak sempurna adalah tujuan pendidikan yang sebenarnya. Kedua, persiapan untuk kehidupan dunia dan kehidupan diakhirat. Pendidikan Islam menaruh penuh untuk perhatian kehidupan tersebut, sebab memang itulah tujuan tertinggi dan terakhir pendidikan. Ketiga, persiapan untuk mencari rizki dan pemeliharaan segi-segi kemanfaatan. Islam memandang, manusia sempurna tidak akan tercapai kecuali memadukan antara ilmu pengetahuan dan agama, atau mempunyai kepedulian (concern) pada aspek spiritual, akhlak dan pada segi-segi kemanfaatan. Keempat,

\footnotetext{
${ }^{8}$ Khoiron Rosyadi, Pendidikan Profetik, (Yogyakarta: Pustaka Pelajar, 2009), 04.

${ }^{9}$ Kuntowijoyo, Islam Sebagai Ilmu: Epistemologi, Metodologi, dan Etika, (Yogyakarta: Tiara Wacana,2007), 50.
} 
The $3^{\text {rd }}$ Annual International Conference on Islamic Education

24-25 Februari 2018

Paradigma Pendidikan Profetik

Muhamad Khoirul Umam - STAI Badrus Sholeh Purwoasri Kediri

menumbuhkan roh ilmiah (scientific spirit) pada peserta didik dan memuaskan keinginan arti untuk mengetahui (co-riosity) dan memungkinkan untuk mengkaji ilmu. Kelima, menyiapkan pelajar dari segi profesional. ${ }^{10}$

Pendidikan yang berwawasan kemanusiaan mengandung pengertian bahwa pendidikan harus memandang manusia sebagai subjek pendidikan. Oleh karena itu,starting point dari proses pendidikan berawal dari pemahaman teologisfilosofis tentang manusia, yang pada akhirnya manusia diperkenalkan akan keberadaan dirinya sebagai khalifah Allah dimuka bumi. Pendidikan yang berwawasan kemanusiaan tidak berpretensi menjadikan manusia sebagai sumber ikatan-ikatan nilai secara mutlak (antroposentris), karena di Eropa pada abad pertengahan menjadikan ilmu murni dan teknologi teistik justru membawa malapetaka di abad modern ini, dimana kepribadian manusia menjadi terpisah-pisah di dalam jeratan dogma materialisme yang mengaburkan nilai kemanusiaan. Padahal pendidikan itu sarat akan nilai dan harus berarsitektur atau landasan moral-transendensi.

Jika kegagalan pendidikan dalam rangka memaksimalkan peran profetiknya karena tidak dapat menempatkan manusia sebagai subjek pendidikan dalam setting teologis-filosofis. Jadi bukan sebagai objek pendidikan, yang menurut Paulo Freire dikatakan sebagai konsep bank. ${ }^{11}$ Oleh karena itu, pendidikan harus kembali pada missi profetik, yaitu memanusiakan manusia (Humanisasi), berijtihad / pembebasan (liberasi), dan keimanan manusia (transendensi).

Selanjutnya, Kuntowijoyo memasukan kata profetik kedalam penemuannya tentang ilmu-ilmu sosial profetik yang mengandung tiga muatan ilmu-ilmu sosial yaitu humanisme, leberasi, dan transendensi. ${ }^{12}$

Secara normatif-konseptual, paradigma profetik versi Kuntowijoyo didasarkan pada Surat Ali-Imran ayat 110 yang terjemahannya:

Artinya: Engkau adalah umat terbaik yang diturunkan/dilahirkan ditengah-tengah manusia untuk menyuruh kepada yang ma'ruf dan mencegah kemunkaran dan beriman kepada Allah. ${ }^{13}$

Dari ayat tersebutlah dasar ketiga pilar nilai ilmu sosial profetik yang digunakan oleh Kuntowijoyo yaitu; 1) Amar Ma'ruf(humanisasi) mengandung pengertian memanusiakan manusia. 2) Nahi Munkar(liberasi) mengandung pengertian pembebasan. 3) Tu'minuna Bilah (transendensi), dimensi keimanan manusia. ${ }^{14}$

Selain itu dalam ayat tersebut juga terdapat empat konsep pendidikan profetik menurut Kuntowijoyo;

Pertama, konsep tentang umat terbaik (The Chosen People), yang menjelaskan bahwa umat Islam sebagai umat terbaik dengan syarat mengerjakan tiga hal sebagaimana disebutkan dalam ayat tersebut. Umat Islam tidak secara otomatis

\footnotetext{
${ }^{10}$ Hasan Langgulung, Asas-Asas Pendidikan Islam, (Jakarta: Al-Husna, 2000), 375.

11 Paulo Freire, Pendidikan Kaum Tertindas, (Yogyakarta: LP3ES, 2011), 52.

12 Kuntowijoyo, Muslim Tanpa Masjid, (Bandung: Mizan, 2001), 357.

${ }^{13}$ Departemen Agama RI, Al Qur'an dan terjemahannya, (Bandung: Sinar Baru Algesindo, 2009), 50.

${ }^{14}$ Kuntowijoyo, Islam Sebagai Ilmu: Epistemologi...., 99.
} 
The $3^{\text {rd }}$ Annual International Conference on Islamic Education

menjadi The Chosen People, karena umat Islam dalam konsep The Chosen People ada sebuah tantangan untuk bekerja lebih keras dan ber-fastabiqul khairat. Kedua, aktivisme atau praksisme gerakan sejarah yang dapat di artikan sebagai sikap bekerja keras dan ber-fastabiqul khairat ditengah-tengah umat manusia (Ukhrijat Linnas) yang terwujud dalam sikap partisipatif umat islam dalam percaturan sejarah. Oleh karenanya pengasingan diri secara ekstrim dan kerahiban tidak dibenarkan dalam Islam. Para intelektual yang hanya bekerja untuk ilmu atau kecerdasan tanpa menyapa dan bergelut dengan realitas sosial juga tidak dibenarkan. Ketiga, pentingnya kesadaran. Nilai-nilai profetik harus selalu menjadi landasan rasionalitas nilai bagi setiap praksisme gerakan dan membangun kesadaran umat, terutama umat Islam. Keempat, etika profetik, ayat tersebut mengandung etika yang berlaku umum atau untuk siapa saja baik itu individu (peserta didik, intelektual, aktivis dan sebagainya) maupun organisasi (gerakan mahasiswa, universitas, ormas, dan orsospol), maupun kolektifitas (jama'ah, umat, kelompok/paguyuban) Point yang terakhir ini merupakan konsekuensi logis dari tiga kesadaran yang telah dibangun sebelumnya. ${ }^{15}$

Selanjutnya, Shofan mengungkapkan konseptualisasi pilar-pilar ilmu sosial profetik pada dasarnya berangkat dari paradigma pendidikan yang berusaha melakukan sintesa antara sistem pendidikan yang konsen terhadap nilai-nilai moral dan religius dengan sistem pendidikan modern yang mengembangkan nilai-nilai kemanusiaan. Dualisme sistem pendidikan yang dikotomis yang dalam konteks Indonesia merupakan dua sisi diametrikal antara pendidikan ala barat yang dinasionalisasi dan pendidikan ala timur yang sudah secara historis telah ada sejak nenek moyang. Pendidikan profetik dapat dikembangkan dalam tiga dimensi yang mengarahkan perubahan atas masyarakat yaitu humanisasi, liberasi dan transendensi. ${ }^{16}$

Lebih lanjut Kuntowijoyo dalam Shofan mengatakan bahwa cita-cita etik dan profetik inilah yang seharusnya diderivasikan dari nilai-nilai yang mengakar pada budaya, ajaran agama dan nilai-nilai moral bangsa sehingga pencapaian cita-cita pendidikan tidak mengorbankan jati diri bangsa. Artinya sistem pendidikan harus memberikan pemahaman nilai-nilai agama dan nilai-nilai inilah yang kemudian menjadi tugas pendidikan untuk melakukan reorientasi konsep-konsep normatif agar dapat dipahami secara empiris. ${ }^{17}$

Landasan pendidikan tersebut sekiranya diorientasikan untuk memfasilitasi terbentuknya kesadaran ilmiah dalam memformulasikan konsep-konsep normatif menjadi konsep-konsep teoritis. Pendekatan deduktif-induktif idealnya diterapkan dalam pembelajaran pengetahuan umum dan pendidikan moral, hal ini lah konsep dasar sebuah pendidikan profetik yang dibutuhkan pada saat ini.

\footnotetext{
15 Kuntowijoyo, Muslim Tanpa Masjid...., 357-358.

16 Mohammad Shofan, Pendidikan Berparadigma Profetik (Upaya Konstruktif Membongkar Dikotomi Sistem Pendidikan Islam), Cet. I, (Yogyakarta: IRCiSoD bekerjasama dengan UMG Press, 2004), 131.

17 Mohammad Shofan "Pendidikan Berparadigma Profetik...., 135.
} 
The $3^{\text {rd }}$ Annual International Conference on Islamic Education

24-25 Februari 2018

Paradigma Pendidikan Profetik

Muhamad Khoirul Umam - STAI Badrus Sholeh Purwoasri Kediri

Sehingga dapat disimpulkan bahwa, pendidikan profetik (Prophetic Teaching) adalah suatu metode pendidikan yang selalu mengambil inspirasi dari ajaran nabi Muhammad saw. Prinsip dalam pendidikan profetik yaitu mengutamakan integrasi. Dalam memberikan suatu materi bidang tertentu juga dikaitkan dengan landasan yang ada di Al Qur'an dan As Sunnah, sehingga tujuan baik duniawi maupun akhirat dapat tercapai.

\section{Memaknai Kerangka Pendekatan Pembelajaran Tematik}

Pendekatan secara ilmiah berarrti konsep dasar yang akan menginspirasi atau membackground perumusan metode mengajar dengan menerapkan karakteristik yang bersifat ilmiah, pendekatan pembelajaran yang merupakan bagian dari pendekatan pendagogis pada pelaksanaanya pembelajaran dalam kelas yang melandasi penerapan metode ilmiah.

Pengertian suatu penerapan pendekatan ilmiah dalam pembelajaran tidak harus fokus pada bagaimana mengembangkan kompetensi peserta didik dalam melakukan observasi atau eksperimen, namun bagaimana mengembangkan pengetahuan dan keterampilan berfikir sehingga dapat mendukung aktivitas kreatif dalam berinovasi atau berkarya.

Pendekatan pembelajaran dimaksudkan guna memberikan pembaruan kepada peserta didik dalam mengenal, memahami berbagai materi menggunakan pendekatan tematik, bahwa informasi bisa berasal dari mana saja, kapan saja, tidak bergantung pada informasi searah dari guru. Oleh karena itu kondisi pembelajaran yang diharapkan tercipta diarahkan untuk mendorong peserta didik dalam mencari tahu dari berbagai sumber melalui observasi, dan bukan hanya dari hasil apa yang diberi tahukan.

Menengok tujuan dan prinsip pendekatan dalam menukil ayat Al Qur'an yang penjelasannya Allah SWT menciptakan manusia sejak dari Rahim ibunya tidak mengetahui apapun, kemudian Allah anugrahi manusia dengan berbagai fasilitas dan perangkat untuk hidup sehingga manusia mampu mengarungi dunia ini dengan baik dan sukses. Hal ini sesuai dengan firman Allah dalam surat An-Nahl ayat 78 yang terjemahannya:

Artinya: Dan Allah mengeluarkan kamu dari perut ibumu dalam keadaan tidak mengetahui sesuatu apapun, dan Dia memberimu pendengaran, penglihatan, dan hati nurani, agar kamu bersyukur. (Qs: An-Nahl:78) ${ }^{18}$

Ayat di atas mengarahkan umat manusia agar membiasakan diri untuk mengamati, karena salah satu fitrah yang manusia bawa sejak lahir adalah cenderung menggunakan mata terlebih dahulu baru menggunakan hati (qollbu).

Berdasarkan hal tersebut, maka proses pembelajaran harus dipandu dengan kaidah kaidah pendekatan pembelajaran tematik. Karena pendekatan pembelajaran tematik ini bercirikan penonjolan dimensi pengamatan, penalaran, penemuan, pengabsahan dan penjelasan tentang suatu kebenaran. Pembelajaran juga berdasarkan

\footnotetext{
${ }^{18}$ Depag RI, Alquran dan terjemahanya, (Jakarta: Balai Pustaka, 2005).
} 
The $3^{\text {rd }}$ Annual International Conference on Islamic Education

ituisi, akal sehat, prasangka, penemuan melalui uji coba, dan berfikir kritis. Disamping itu juga proses pembelajaran harus juga di ilhami sifat-sifat dan nilai-nilai akhlak religius sebagai pembentukan karakter yang bersifat individu serta secara makro sebagai pembentukan karakter bangsa.

Dalam penerapan pendekatan pembelajaran tematik kegiatan pembelajaran meliputi tiga kegiatan pokok, yaitu kegiatan pendahuluan, kegiatan inti, dan kegiatan penutup. Kegiatan pendahuluan bertujuan untuk menciptakan suasana awal pembelajaran yang efektif dan efesien yang memungkinkan peserta didik dapat mengikuti proses pembelajaran dengan baik. Sebagai contoh ketika memulai pembelajaran, pendidik menyapa peserta didik dengan salam pembuka diimbangi nada semangat dan gembira (salam sebagai karakter religius), mengecek kehadiran para siswa dan menanyakan ketidak hadiran peserta didik apabila ada yang tidak hadir (penanaman karakter jujur).

Dalam metode pendekatan pembelajaran tematik tujuan kegiatan pendahuluan adalah memantapkan pemahaman peserta didik terhadap konsep-konsep yang telah dikuasai yang berkaitan dengan materi pelajaran baru yang akan dipelajari oleh peserta didik. Dalam kegiatan ini pendidik harus berusaha mengupayakan agar peserta didik yang belum paham suatu konsep dapat memahami konsep tersebut, sedangkan peserrta didik yang mengalami kesalahan konsep, kesalahan tersebut dapat dihilangkan. Pada kegiatan pendahuluan, disarankan guru menunjukkan fenomena atau kejadian yang unik dan aneh (discrepant event) yang dapat menggugah timbuya pertanyaan pada diri peserta didik.

Kegiatan inti merupakan kegiatan utama dalam proses pembelajaran atau dalam proses penguasaan pengalaman belajar (learning experience) peserta didik. Kegiatan inti dalam pembelajaran adalah suatu proses pembentukan pengalaman dan kemampuan peserta didik secara terprogam yang dilaksanakan dalam durasi tertentu. Kegiatan inti dalam metode pendekatan pembelajaran tematik ditunjukan untuk terkonstruksinya konsep, hukum atau prinsip oleh peserta didik dengan bantuan dari pendidik melalui langkah-langkah kegiatan yang diberikan di muka.

Kegiatan penutup ditunjukkan unntuk dua hal pokok, pertama, validasi terhadap konsep, hukum atau prinsip yang telah dibangun oleh peserta didik. Kedua, pengayaan materi pelajaran yang dikuasai oleh peserta didik.

\section{Nilai-Nilai Profetik Sebagai Perspektif Karakter Religius Peserta Didik}

Desentralisasi pendidikan Indonesia merupakan peluang yang sangat baik untuk meningkatkan demokrasi pendidikan, efesiensi manajemen pendidikan, relevansi pendidikan, dan mutu pendidikan. Dengan desentralisasi pendidikan daerah terpacu untuk memberikan pelayanan pendidikan yang baik kepada semua anak, termasuk anak-anak yang berada di daerah terpencil dan anak-anak kurang beruntung, minimal sesuai tuntutan wajib belajar pendidikan dasar Sembilan tahun. Desentralisasi pendidikan juga memberikan keleluasan bagi madrasah untuk maju dan berkembang 
The $3^{\text {rd }}$ Annual International Conference on Islamic Education

24-25 Februari 2018

Paradigma Pendidikan Profetik

Muhamad Khoirul Umam - STAI Badrus Sholeh Purwoasri Kediri

sesuai dengan core value yang dibangun dan dikembangkan untuk menjadi madrasah yang unggul dan diminati oleh masyarakat. ${ }^{19}$

Pendidikan Islam merupakan bagian yang tidak terpisahkan dari sistem pendidikan di Indonesia. Hal ini diwujudkan dengan adanya sekolah-sekolah yang bercirikan Islam seperti Bustanul Atfal (TK), Madrasah Ibtidaiyah (SD), Madrasah Tsanawiyah (SMP), Madrasah Aliyah (SMU), dan Perguruan Tinggi Islam baik dikelola swasta ataupun negeri, serta adanya pesantren-pesantren baik salafi maupun modern.

Kenyataan ini merupakan sesuatu yang menggembirakan bagi perkembangan umat Islam untuk waktu yang akan datang, karena diharapkan dengan munculnya sekolah-sekolah Islam akan memberikan dampak yang positif bagi terciptanya generasi (peserta didik) yang Islami. Wajah Islam akan semakin dikenal oleh dunia melalui pendidikan.

Kondisi lain akan tercipta juga ketika pendidikan Islam melalaui madrasahmadrasahnya tidak menerapkan pendidikan seutuhnya seperti pernah disinggung oleh Chabib Thoha bahwa tujuan pendidikan Islam adalah pembentukan insan kamil (manusia menyeluruh) artinya pendidikan Islam tidak hanya mementingkan satu aspek pengetahuan saja, akan tetapi pendidikan apapun bentuknya pendidikan itu paling tidak berorientasi pada tiga aspek dasar seperti dikatakan Blomm, yaitu berorientasi pada aspek kognitif, afektif, dan psikomotorik.

Kondisi lain yang menjadi kekhawatiran itu ialah semakin banyaknya kasus narkoba, minum-minuman keras, kenakalan remaja, kemudian setelah menjadi pejabat akan korup dan masih banyak kejahatan-kejahatan lainnya. Hal inilah yang perlu mendapatkan perhatian serius agar Islam tidak hanya sekedar simbol-simbol akan tetapi mempunyai subtansi kuat untuk menciptakan bangsa yang kuat dan berkarakter meminjam dari filsafat jawa- gemah ripah loh jinawi tata tentrem kertoraharjo.

Hasil pencarian penulis untuk menjawab rumusan masalah nilai-nilai profetik sebagai perspektif karakter religius peserta didik dalam pembentukan karakter yang ideal mengarah kepada firman Allah Swt. Dalam surat al Ahzab ayat 21yang terjemahanya sebagai berikut ini:

Artinya: Sesungguhnya telah ada pada (diri) Rasulullah itu suri teladan yang baik bagimu (yaitu) bagi orang yang mengharap (rahmat) Allah dan (keselamatan) hari kiamat dan dia banyak mengingat Allah. (QS Al-Ahzab: 21) ${ }^{20}$

Ayat tersebut memberikan petunjuk bahwa Rasulullah Saw. merupakan contoh yang baik bagi manusia di berbagai bidang. Nilai kenabian tersebut atau juga disebut sebagai nilai profetik itulah yang harus menjadi orientasi peserta didik dalam pengembangan karakter (character building) dirinya.

\footnotetext{
19 Muhamad Khoirul Umam, Strategi Alternatif Memajukan Lembaga Pendidikan Islam Pedesaan, PROCEEDING $1^{\text {st }}$ Annual Conferrence For Muslim Scholars (ANCOMS), (Surabaya: Kopertais IV perss, 2017), ISBN: 978-602-61613-0-7, hlm 773

${ }^{20}$ Departemen Agama RI, Al-Qur'an dan Terjemahnya Al-Jumanatul 'Ali, (Bandung: J-Art, 2005),
} 
The $3^{\text {rd }}$ Annual International Conference on Islamic Education

Profetik sendiri berarti nilai kenabian yang digali dari cara Rasul Saw. semasa hidupnya. Nilai profetik pun masih dipandang sebagai sebuah konsep karakter paling sukses dan adaptatif dalam membentuk tatanan kehidupan peserta didik berkualitas. Nilai ini selayaknya diimplementasikan ke dalam model kehidupan di berbagai lingkup: organisasi sosial, perdagangan, pendidikan, pemerintahan, dan lainya. ${ }^{21}$

Menurut Ustadz Syafi'i Antonio, nilai profetik adalah esensi yang sepatutnya mendasari gerak langkah manusia dalam beraktivitas apapun bentuknya (berdagang, berpolitik, berkeluarga, berpendidikan dan sebagainya). Namun realita yang ada, masyarakat pendidikan Indonesia justru melupakan esensi dari sifat-sifat kerasulan Nabi Muhammad Saw. Rasulullah tidak dibawa dalam kehidupan pendidikan. Saat seseorang pendidik, ia lupa bagaimana cara Rasulullah menyampaikan pendidikan kepada umatnya. Rasulullah Saw. menjadi sosok yang dekat, namun esensinya sebagai sosok suri teladan dilupakan.

Nilai-nilai profetik dapat dipelajari dari sifat-sifat kenabian yang ada pada diri Rasulullah Saw. Berikut inilah sifat-sifat kenabian Rasulullah Saw. yang bisa menjadi inspirasi bagi peserta didik dalam pembentukan jati diri masyarakat pendidikan yang Islami: ${ }^{22}$

Sidiq (Integrity) Secara sederhana sifat sidiq dapat diartikan sebagai kejujuran. Namun secara luas, sidiq juga merupakan sebuah integritas moral yang dimiliki oleh peserta didik. Kejujuran dinilai sebagai sebuah modal mendasar dalam membentuk integritas. Kejujuran ini juga merupakan wujud nilai-nilai transendental yang mengarah pada kebenaran yaitu Allah Swt (QS Al Maaidah: 8). Sifat jujur dapat dilatih dengan cara mendapatkan rizki yang halal. Rizki yang halal (didapatkan dengan cara jujur) adalah hal mendasar dari pembentukan integritas karena kejujuran adalah sifat yang hanya dapat dinilai oleh diri sendiri peserta didik.

Amanah (Responsible) juga dapat diartikan sebagai sifat terpercaya. Sifat ini melatih peserta didik pada sifat bertanggung jawab dan dapat diandalkan $(\mathrm{QS}$ Al Anfaal: 27). Karakter amanah akan dapat mengasah speserta didik dalam memilah dan memilih antara kepentingan pribadi dan kepentingan publik (QS An Nissa: 58). Karakter ini dapat dilatih dengan cara mengemban tugas. Tugas yang berat akan semakin membentuk kualitas amanah yang baik pada diri seseorang peserta didik. Oleh sebab itu jangan pernah takut untuk mengambil sebuah kepercayaan untuk memimpin dan menjalankan tugas.

Fathanah (Smart) adalah karakter peserta didik dengan kualitas diri (capacity building) yang baik. Kualitas diri mencakup pada kecerdasan spiritual dan intelektual (QS. Al Mujaadilah: 11) dan keterampilan (skillful). Kecerdasan akan memberikan kepekaan peserta didik dalam mengambil keputusan dan memecahkan masalah. Sifat ini dapat dilatih dengan selalu menjadi pembelajar yang baik seumur

\footnotetext{
${ }^{21}$ Mujtahid, Tujuh Karakteristik Kepemimpinan Profetik, (Malang: UIN Maliki, 2011).

22 Ibid.
} 
The $3^{\text {rd }}$ Annual International Conference on Islamic Education

24-25 Februari 2018

Paradigma Pendidikan Profetik

Muhamad Khoirul Umam - STAI Badrus Sholeh Purwoasri Kediri

hidup dengan berbagai cara yang didapat dari pengalaman diri sendiri, pengalaman orang lain, buku, dan berbagai sumber lainnya (QS Al Alaq: 3-5).

Tabligh (Communicative) dapat pula diartikan sebagai kemampuan komunikasi yang efektif. Dengan komunikasi yang efektif (Al Hajj: 24), maka peserta didik dapat dengan mudah untuk menyampaikan visi dan misinya kepada peserta didik lainnya (Az Zumar: 18). Komunikasi juga dipercaya sebagai kunci kesuksesan nomor satu. Karakter ini dapat dilatih dengan cara berani berbicara di depan publik dan berani menyampaikan pendapat.

Keempat sifat itulah yang penulis sebutkan sebagai sifat profetik atau kenabian. Sifat-sifat yang sepatutnya menjadi pedoman peserta didik untuk membentuk karakter diri (character building) demi meningkatkan kualitas diri secara vertikal (hablun min Allah) maupun horizontal (hablun min al-nas).

Nilai-nilai ini pulalah yang berperan dalam mengarahkan tujuan pendidikan Indonesia. Dengan membentuk karakter dan sifat kenabian serta menjalankan tugas kerja kenabian di atas, maka perdaban pendidikan Islami di Indonesia InsyaAllah dapat dibangun. Jati diri pendidikan Islam yang selama ini terkikis dapat kembali dibentuk. Keterpojokan pendidikan Islam Indonesia karena tidak dapat menciptakan kondisi masyarakat pendidikan yang adil dan sejahtera dapat diputarbalikan. Tentu dengan senantiasa berdoa dan mengharap kemudahan dari Allah Swt. dalam melakukan perjuangan dan perubahan bagi agama, nusa, dan bangsa.

\section{KESIMPULAN}

Landasan pendidikan profetikt sekiranya diorientasikan untuk memfasilitasi terbentuknya kesadaran ilmiah dalam memformulasikan konsep-konsep normatif menjadi konsep-konsep teoritis. Pendekatan deduktif-induktif idealnya diterapkan dalam pembelajaran pengetahuan umum dan pendidikan moral, hal ini lah konsep dasar sebuah pendidikan profetik yang dibutuhkan pada saat ini. Sehingga dapat disimpulkan bahwa, pendidikan profetik (Prophetic Teaching) adalah suatu metode pendidikan yang selalu mengambil inspirasi dari ajaran nabi Muhammad saw. Prinsip dalam pendidikan profetik yaitu mengutamakan integrasi. Dalam memberikan suatu materi bidang tertentu juga dikaitkan dengan landasan yang ada di Al Qur'an dan As Sunnah, sehingga tujuan baik duniawi maupun akhirat dapat tercapai.

Dalam penerapan pendekatan pembelajaran tematik kegiatan pembelajaran meliputi tiga kegiatan pokok, yaitu kegiatan pendahuluan, kegiatan inti, dan kegiatan penutup. Kegiatan pendahuluan bertujuan untuk menciptakan suasana awal pembelajaran yang efektif dan efesien yang memungkinkan peserta didik dapat mengikuti proses pembelajaran dengan baik. Kegiatan inti dalam metode pendekatan pembelajaran tematik ditunjukan untuk terkonstruksinya konsep, hokum atau prinsip oleh peserta didik dengan bantuan dari pendidik melalui langkah-langkah kegiatan yang diberikan di muka. Kegiatan penutup ditunjukkan unntuk dua hal pokok, pertama, validasi terhadap konsep, hukum atau prinsip yang telah dibangun oleh peserta didik. Kedua, pengayaan materi pelajaran yang dikuasai oleh peserta didik. 
The $3^{\text {rd }}$ Annual International Conference on Islamic Education

Keempat sifat Rasulullah Integrity, Responsible, Smart, Communicative sebagai sifat profetik atau kenabian. Sifat-sifat yang patut menjadi pedoman peserta didik sehingga membentuk karakter diri (character building) dalam meningkatkan kualitas diri secara vertikal (hablun min Allah) maupun horizontal (hablun min al-nas). Nilai-nilai ini pulalah yang berperan dalam mengarahkan tujuan pendidikan Indonesia. Dengan membentuk karakter dan sifat kenabian serta menjalankan tugas kerja kenabian di atas, maka perdaban pendidikan Islami di Indonesia InsyaAllah dapat dibangun. Jati diri pendidikan Islam yang selama ini terkikis dapat kembali dibentuk. Keterpojokan pendidikan Islam Indonesia karena tidak dapat menciptakan kondisi masyarakat pendidikan yang adil dan sejahtera dapat diputarbalikan.

\section{Daftar Pustaka}

Az-Zain, Muhammad Basyam Rusydi, Sekolah Para Nabi 1 \& 2. (Yogyakarta: Pustaka Marwa, 2007),

Departemen Agama RI, Al Qur'an dan terjemahannya, (Bandung: Sinar Baru Algesindo, 2009)

Departemen Agama RI, Al-Qur'an dan Terjemahnya Al- Jumanatul 'Ali, (Bandung: J-Art, 2005),

Fahmi, M., Islam Transendental: Menelusuri Jejak-jejak Pemikiran Islam Kuntowijoyo, (Yogyakarta: Pilar Religia, 2005)

Freire, Paulo, Pendidikan Kaum Tertindas, (Yogyakarta: LP3ES, 2011)

Kuntowijoyo, Muslim Tanpa Masjid, (Bandung: Mizan, 2001)

Kuntowijoyo, Islam Sebagai Ilmu: Epistemologi, Metodologi, dan Etika, (Yogyakarta: Tiara Wacana,2007)

Kuntowijoyo, Paradigma Islam: Interpretasi Untuk Aksi, (Bandung: Mizan, 1991)

Langgulung, Hasan, Asas-Asas Pendidikan Islam, (Jakarta: Al-Husna, 2000)

Ma'arif , Ahmad Syafii, Islam dalam Bingkai Kemanusiaan dan Keindonesiaan (Bandung: Mizan, 2009)

Mujtahid, Tujuh Karakteristik Kepemimpinan Profetik, (Malang: UIN Maliki, 2011).

Rosyadi, Khoiron, Pendidikan Profetik, (Yogyakarta: Pustaka Pelajar, 2009)

Shari'ati, Ali, Humanisme: Antara Islam dan Mazhab Barat, terj. Husein Anis al- Habshi, (Bandung: Pustaka Indah, 1996)

Shofan, Moh., Pendidikan Berparadigma Profetik (Upaya Konstruktif Membongkar Dikotomi Sistem Pendidikan Islam), (Yogyakarta: IRCiSoD, 2004)

Umam, Muhamad Khoirul, Strategi Alternatif Memajukan Lembaga Pendidikan Islam Pedesaan, PROCEEDING $1^{\text {st }}$ Annual Conferrence For Muslim Scholars (ANCOMS), (Surabaya: Kopertais IV perss, 2017), ISBN: 978-602-61613-0-7, hlm 773 